\title{
Isolation and Partial Characterization of a Filamentous Virus Associated with Peach Mosaic Disease
}

\author{
D. James, Centre for Plant Health, Canadian Food Inspection Agency, Sidney, B. C., Canada; and W. E. Howell, \\ Washington State University, Prosser 99350
}

\begin{abstract}
James, D., and Howell, W. E. 1998. Isolation and partial characterization of a filamentous virus associated with peach mosaic disease. Plant Dis. 82:909-913.

A filamentous virus, $752 \mathrm{~nm}$ long by $9.25 \mathrm{~nm}$ wide and with striations of $3.47 \mathrm{~nm}$ in pitch, was isolated from peach mosaic-affected peach. The peach mosaic-associated virus (PMV) has a coat protein subunit molecular mass of $20.5 \mathrm{kDa}$, and dsRNA bands of 7.0, 6.4, 4.2, and $1.9 \times$ $10^{6} \mathrm{Da}$, with a number of bands of lower molecular mass ranging in size from 1.3 to $0.3 \times 10^{6}$ Da. The herbaceous host range of PMV includes Chenopodium amaranticolor, C. quinoa, and Nicotiana occidentalis "37B." The virus was successfully bud-transmitted from infected peach to peach indicator plants, cv. Elberta, which displayed typical peach mosaic symptoms. Attempts to transmit PMV to Prunus avium cv. Bing and P. mahaleb were unsuccessful. In serological assays, PMV polyclonal antibody (PAb) cross-reacted with cherry mottle leaf virus (CMLV). CMLV PAb and CMLV monoclonal antibodies cross-reacted with all isolates of PMV tested. Blocking with skim milk had no effect on the cross-reactions observed. PMV was consistently associated with peach mosaic disease, and the bud transmission studies and serological data suggest that this virus is the causal agent of peach mosaic disease. Data indicating that there is no relationship between peach latent mosaic viroid and peach mosaic disease was also obtained. PMV and CMLV appear to be closely related viruses, with identical coat protein subunit size and dsRNA profiles.
\end{abstract}

Peach mosaic disease was first observed in Colorado (2,3) and Texas in 1931 (7). The disease was subsequently found in Arizona, Arkansas, California, New Mexico, Oklahoma, Utah, and in 11 states in Mexico $(19,20)$. Symptoms of the disease are influenced by the host species, the isolate, and the nature of any accompanying viruses which may simultaneously infect the host $(15,17)$. Peach mosaic disease affects several stone fruit species including almond (Prunus dulcis (Mill.) D.A. Webb), apricot (P. armeniaca L.), peach (P. persica (L.) Batsch), and plum (P. domestica L.; 17). Symptoms on susceptible peach cultivars may include color break in the petals, retarded foliation, mottling and deformity of leaves, fruit deformity, and stunted growth of the plants. The disease has significant economic impact on the industry in the western United States, and the agent is an important quarantine pest.

The disease agent is spread by the peach bud mite, Eriophyes insidiosus Keifer \& Wilson (13). Larsen and Oldfield (15) in-

Corresponding author: D. James

E-mail: jamesd@em.agr.ca

Accepted for publication 22 April 1998.

Publication no. D-1998-0615-02R

This article is in the public domain and not copyrightable. It may be freely reprinted with customary crediting of the source. The American Phytopathological Society, 1998. dicated that the mite is windborne and that a single mite can transmit the disease agent from an infected to a healthy tree. This may in part be responsible for the rapid spread of this disease. Miticide application to reduce or eliminate the population of vector mites has been suggested as one approach to controlling this disease, and the use of certified nursery stock has also been recommended $(15,17,21)$.

The causal agent of peach mosaic disease was assumed to be a virus because the agent is graft transmissible, and because of the associated symptomatology $(17,21)$. It has also been suggested that a viroid, peach latent mosaic viroid (PLMVd), may be associated with the disease (5).

Recently, the causal agent of cherry mottle leaf disease was identified as a filamentous virus (CMLV; 9,11). The virus was purified and polyclonal (PAb) and monoclonal antibodies (MAbs) produced for use in rapid indexing procedures based on serology. In studies to determine the specificity of the CMLV-associated antibodies, cross-reactions of the PAb and MAbs were observed with peach mosaicaffected material when tested by enzymelinked immunosorbent assay (ELISA) and Western blot analysis (10). A CMLV-associated MAb has subsequently been used in a survey to determine the incidence and distribution of peach mosaic disease in Mexico (20).

In the present study, experiments were conducted to isolate the virus associated with peach mosaic disease, to transmit the virus to herbaceous and woody hosts, and to determine the relationship of PLMVd to peach mosaic disease. The results of these experiments are reported.

\section{MATERIALS AND METHODS}

Virus source. Virus isolate CA-1 (Chino isolate) was originally found in an infected flowering peach tree in the San Bernadino area, California, and subsequently transmitted to healthy peach by bud mite ( $E$. insidiosus) transmission. Isolate CA-2 (Riverside isolate) was maintained in peach and in nectarine, but it was originally found in a flowering peach in Riverside, California. Isolate CA-3 (Imperial Valley isolate) was obtained in peach, and isolate CO-2 (Funk isolate) originated from Mesa County, Colorado. All peach mosaic isolates were supplied by H. J. Larsen, Agricultural Experiment Station, Colorado State University. The CMLV isolate Sa1162-21 was maintained in Bing cherry and Chenopodium quinoa Willd. at the Centre for Plant Health, Sidney, British Columbia.

Bud transmission. Single, healthy, dormant buds of the indicator cultivars Elberta peach and Bing cherry were chip budded onto four trees each of 1-year-old peach and mahaleb seedlings, respectively. Two inoculum bark chips from a peach mosaic-affected peach, infected with isolate CA-1, were grafted just below the indicator buds. A parallel experiment was carried out using buds from a known mottle leaf-affected cherry as inoculum; the source plant had previously tested positive on Bing indicators and by serological assay. After 1 week, the double budded trees were pruned back to just above the indicator buds to force their growth. These inoculated trees, together with non-inoculated controls, were kept under natural light in glass greenhouses in which the temperature was never allowed to fall below $18^{\circ} \mathrm{C}$ but otherwise fluctuated in response to changes in ambient conditions.

Mechanical transmission. Young symptomatic leaves of Elberta plants displaying symptoms of peach mosaic were triturated in $0.03 \mathrm{M}$ potassium phosphate buffer, $\mathrm{pH} 7.0$, containing $0.02 \mathrm{M}$ mercaptoethanol and $1 \%$ polyvinylpyrrolidone, molecular mass $=10,000$ (PPMP buffer). The inoculum was gently rubbed onto leaves of $C$. quinoa previously dusted with corundum (grit 600). The herbaceous host range of the virus was determined by tritu- 
rating symptomatic leaves of $C$. quinoa in either $0.03 \mathrm{M}$ potassium phosphate buffer, or $0.05 \mathrm{M}$ Tris with $0.01 \mathrm{M}$ magnesium sulphate, final $\mathrm{pH}$ 8.5. The inoculum was used to gently sap inoculate corundumdusted leaves on each of three seedlings of the tested herbaceous species. Prior to inoculation, seedlings were kept in the dark for $24 \mathrm{~h}$. The following species were inoculated: C. amaranticolor Coste \& Reyn., C. foetidum Schrad., C. quinoa, Cucumis sativus L., Gomphrena globosa L., Lycopersicon esculentum Mill., Nicotiana benthamiana Domin., N. clevelandii Gray, and N. occidentalis Wheeler "37B."

Polyclonal antibody production. The virus isolated from peach mosaic-affected Elberta (isolate CA-1) was transmitted to and propagated in the herbaceous host $C$. quinoa. Infected leaves of $C$. quinoa were collected 21 days post-inoculation and the virus purified using the CMLV purification procedure of James and Mukerji (11). An extinction coefficient of $2.02 \mathrm{mg}^{-1} \mathrm{ml}^{-1}$ $\mathrm{cm}^{-1}$, determined for apple chlorotic leaf spot virus (1), was used to estimate virus yield. Approximately $120 \mu \mathrm{g}$ of purified PMV, isolate CA-1, in $0.3 \mathrm{ml}$ of $0.01 \mathrm{M}$ potassium phosphate buffer was mixed with an equal volume of Freund's complete adjuvant for the initial injection of each of two New Zealand white rabbits. This was followed, at 2-week intervals, by injections of $100 \mu \mathrm{g}$ of the antigen in Freund's incomplete adjuvant. All injections were intramuscular and serum was collected 5 days after the final injection.

Electron microscopy. Electron microscope observations and immunosorbent electron microscopy (ISEM) for PMV and CMLV were conducted on sap from infected leaves and on purified virus preparations, as described (11). The antibodies assessed in ISEM studies included PMV PAb, CMLV PAb, CMLV MAb 1162-A2,

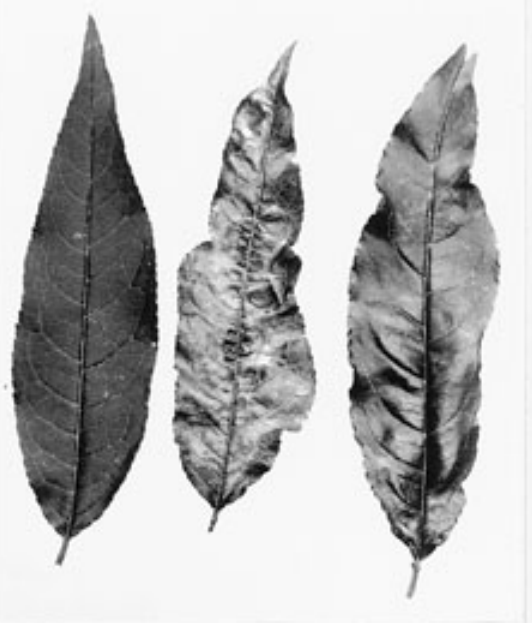

Fig. 1. Elberta peach leaves; (left) from healthy plant, and (middle and right) peach mosaic virus-inoculated plant showing typical peach mosaic symptoms. and CMLV MAb 1162-C2 (12). The antibodies were used at a concentration of $1: 1,000(\mathrm{vol} / \mathrm{vol})$ for trapping and at a concentration of 1:100 (vol/vol) for decoration. All dilutions were carried out using $0.06 \mathrm{M}$ potassium phosphate buffer, $\mathrm{pH}$ 7.0. In preliminary studies these concentrations had been found to be optimal when any reaction was observed.

ELISA. Two types of indirect ELISA, plate-trapped antigen (PTA) and antibodytrapped antigen (ATA) as described by Torrance (23), were used for the detection of PMV or CMLV. Crude extracts of the antigen were prepared by triturating young leaves of infected Prunus spp. or C. quinoa in $0.01 \mathrm{M}$ potassium phosphate buffer $(\mathrm{pH}$ 7.0) containing $0.02 \mathrm{M}$ diethyldithiocarbamic acid, sodium salt, $0.04 \mathrm{M}$ sodium thioglycolate (ST), and $0.5 \%$ nicotine. The extract was centrifuged at $10,000 \times g$ for $10 \mathrm{~min}$ in a Sorvall SS-34 rotor. The supernatant was collected and used as the sample. In ATA-ELISA, Linbro/Titertek microtiter plates (ICN Pharmaceuticals Canada Ltd., Montreal) were coated with either PMV PAb or CMLV PAb diluted 1:2000 in carbonate coating buffer. After adding the antigen, the second antibody used was either CMLV-MAb 1162-A2 or 1162-C2 at a concentration of 1:2000. Goat anti-mouse alkaline phosphatase conjugate was used at a dilution of 1:2000. All dilutions were carried out using the blocking solution, which consisted of phosphate-buffered saline containing $0.05 \%$ Tween 20, pH 7.4 (PBST), with either $1 \%$ bovine serum albumin (BSA) or 5\% skim milk. The substrate $p$ nitrophenyl-phosphate was used at a concentration of $1.0 \mathrm{mg} \mathrm{ml}^{-1}$ in a $10 \%$ diethanolamine buffer, $\mathrm{pH} 9.8$
In the PTA-ELISA, Linbro/Titertek microtiter plates were coated with the antigen extract prepared as described above. The plates were blocked with PBST containing either $1 \%$ BSA or $5 \%$ skim milk. Antibody preparations (PMV PAb, CMLV PAb, and CMLV MAb1162-A2 or C2) were diluted $1: 1000,1: 1000,1: 2000$, and $1: 2000$, respectively, in the blocking solution. Goat anti-rabbit (with PAbs) and goat antimouse (with MAbs) alkaline phosphate conjugates were used at a dilution of 1:2000 in the blocking solution. The substrate was used as described above.

Western blot analysis. Samples were prepared by triturating $0.5 \mathrm{~g}$ of leaf tissue in $2.5 \mathrm{ml}$ of $0.01 \mathrm{M}$ potassium phosphate buffer containing $0.04 \mathrm{M}$ ST and $0.5 \%$ nicotine, final $\mathrm{pH} 9.5$. The samples were centrifuged at $10,000 \times g$ for $10 \mathrm{~min}$. in a Sorvall SS 34 rotor, and $10 \mu \mathrm{l}$ of the supernatant was combined with $10 \mu \mathrm{l}$ of sample loading buffer (0.06 M Tris-HCl, $\mathrm{pH} 6.8$, containing $2 \%$ sodium dodecyl sulfate [SDS], 5\% mercaptoethanol, $10 \%$ glycerol, and $0.2 \%$ bromophenol blue). The mixture was boiled for $5 \mathrm{~min}$, placed on ice immediately thereafter, and the proteins separated by SDS-polyacrylamide gel electrophoresis (PAGE), as described by Laemmli (14). The proteins were transferred from the SDS-PAGE gel to OPTITRAN-supported nitrocellulose membrane (Schleicher \& Schuell, Keene, NH) $0.45-\mu \mathrm{m}$ pore size, by electroblotting using a BIO-RAD Semi-Dry Transfer cell per Bio-Rad instructions (Bio-Rad Laboratories [Canada] Ltd., Mississauga, Ontario). PMV PAb, CMLV PAb, and CMLV MAbs A2 and C2 were assessed for their use in the detection of PMV. CMLV samples were included in these studies as controls and for com-
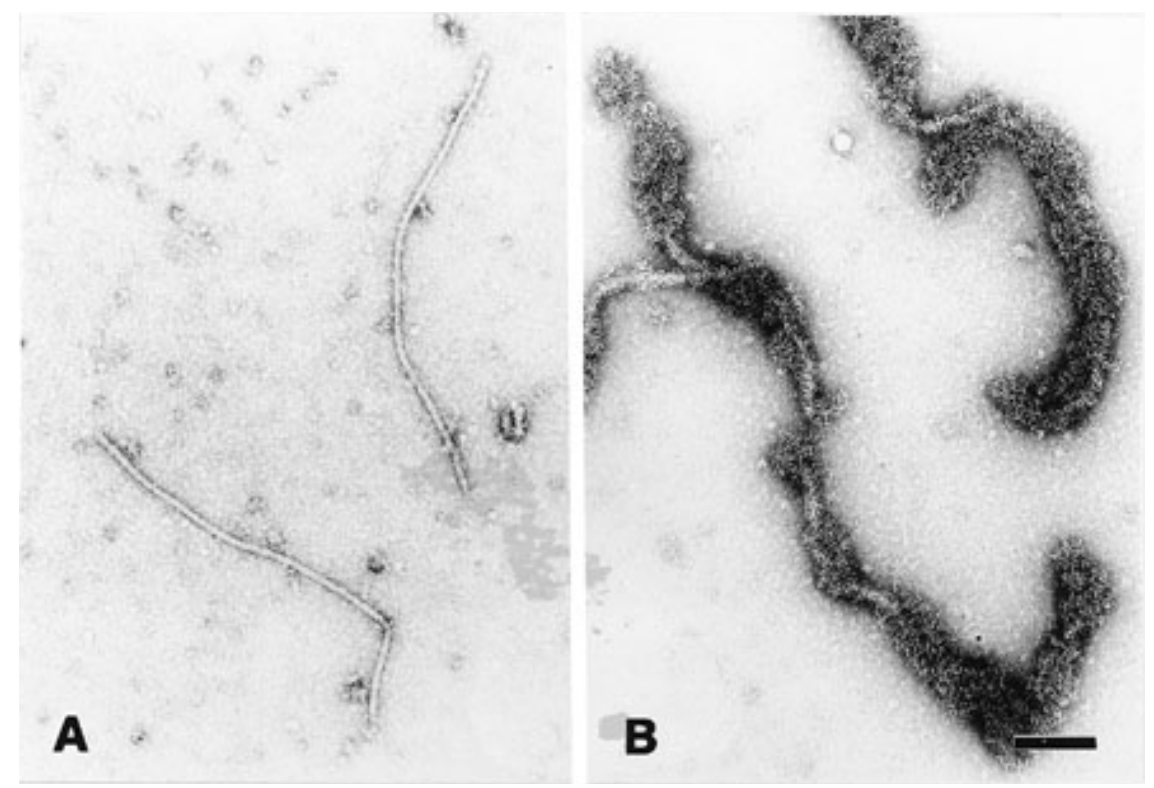

Fig. 2. Electron micrographs showing (A) peach mosaic virus particles trapped with cherry mottle leaf virus polyclonal antibody (CMLV PAb) at a concentration of 1:1,000 but undecorated and (B) CMLV particles trapped and partially decorated with CMLV PAb at concentrations of 1:1,000 and $1: 100$, respectively. Bar $=117 \mathrm{~nm}$. 
parison. BSA (1\%) and skim milk (5\%) were assessed individually as blocking agents. Goat anti-rabbit or goat anti-mouse alkaline phosphatase conjugate (Bio-Rad) at a concentration of 1:2000 was used as the secondary antibody. Nitroblue tetrazolium and 5-bromo-4-chloro-3-indoyl phosphate substrates were used as recom-

Double stranded RNA (dsRNA) extraction. dsRNA was extracted from the $C$. quinoa leaves infected with CMLV, $C$. quinoa infected with PMV, and healthy $C$. quinoa, using a procedure similar to that described by Morris and Dodds (16).

Viroid assay. Leaves were collected from healthy Boone County seedlings, healthy Elberta peach plants, peach mosaic-infected Boone County seedlings, peach mosaic-infected Elberta plants, and from PLMVd (isolate D165)-infected Boone County seedlings and Elberta plants. The leaf petioles were cut and tissue blots obtained by pressing the freshly mended by the supplier (Bio-Rad).

cut surface onto Nytran membranes (Schleicher \& Schuell). The membranes were probed by hybridization with a ${ }^{32} \mathrm{P}$ labeled PLMVd-specific cRNA probe (6), and the blots autoradiographed for $24 \mathrm{~h}$ at $-70^{\circ} \mathrm{C}$ using Kodak XAR5 film with intensifying screens (22).

\section{RESULTS}

Bud transmission. PMV isolate CA-1 was successfully bud-transmitted from an infected peach plant to the Elberta indicators. Typical peach mosaic symptoms were observed on Elberta within 6 weeks (Fig. 1). The presence of PMV was confirmed by both ELISA and Western blotting using either PMV-PAb or CMLV PAbs and MAbs. All inoculated Elberta plants tested positive. When assayed by ELISA and Western blotting, the buffer-inoculated control trees and the inoculated Bing cherry and mahaleb cherry rootstocks gave negative results in repeated experiments. No symptoms were observed on any of

Table 1. Homologous and heterologous serological reactions with cherry mottle leaf virus (CMLV) and peach mosaic virus (PMV)

\begin{tabular}{|c|c|c|c|c|c|c|c|c|}
\hline \multirow[b]{2}{*}{ Technique } & \multicolumn{2}{|c|}{ Use of antibody } & \multirow[b]{2}{*}{ CMLV } & \multicolumn{4}{|c|}{ PMV isolate } & \multirow[b]{2}{*}{$\mathbf{H}^{\mathbf{a}}$} \\
\hline & Trapping & Detecting & & CA1 & CA2 & CA3 & $\mathrm{CO} 2$ & \\
\hline \multirow[t]{8}{*}{$\mathrm{EM}^{\mathrm{b}}$} & PMV PAb & & $+^{\mathrm{d}}$ & + & $\ldots$ & $\ldots$ & $\ldots$ & - \\
\hline & CMLV PAb & & + & + & $\ldots$ & $\ldots$ & $\ldots$ & - \\
\hline & & PMV PAb & - & - & $\ldots$ & $\ldots$ & $\ldots$ & - \\
\hline & & CMLV PAb & + & - & $\ldots$ & $\ldots$ & $\ldots$ & - \\
\hline & CMLV A2 & & - & - & $\ldots$ & $\ldots$ & $\ldots$ & - \\
\hline & CMLV C $2^{e}$ & & - & - & $\ldots$ & $\ldots$ & $\ldots$ & - \\
\hline & & CMLV A2 & - & - & $\ldots$ & $\ldots$ & $\ldots$ & - \\
\hline & & CMLV C2 & - & - & $\ldots$ & $\ldots$ & $\ldots$ & - \\
\hline \multirow[t]{4}{*}{ PTA-ELISA $^{\mathrm{f}}$} & & PMV PAb & + & + & $\ldots$ & $\ldots$ & $\ldots$ & - \\
\hline & & CMLV PAb & + & + & $\ldots$ & $\ldots$ & $\ldots$ & - \\
\hline & & CMLV A2 & + & + & + & + & + & - \\
\hline & & CMLV C2 & + & + & $\ldots$ & $\ldots$ & $\ldots$ & - \\
\hline \multirow[t]{4}{*}{ ATA-ELISA $^{\mathrm{f}}$} & PMV PAb & CMLV A2 & + & + & $\ldots$ & $\ldots$ & $\ldots$ & - \\
\hline & PMV PAb & CMLV C2 & + & + & $\ldots$ & $\ldots$ & $\ldots$ & - \\
\hline & CMLV PAb & CMLV A2 & + & + & $\ldots$ & $\ldots$ & $\ldots$ & - \\
\hline & CMLV PAb & CMLV C2 & + & + & $\ldots$ & $\ldots$ & $\ldots$ & - \\
\hline \multirow{4}{*}{ Western blot } & & PMV PAb & + & + & $\ldots$ & $\ldots$ & $\ldots$ & - \\
\hline & & CMLV PAb & + & + & $\ldots$ & $\ldots$ & $\ldots$ & - \\
\hline & & CMLV A2 & + & + & + & + & + & - \\
\hline & & CMLV C2 & + & + & $\ldots$ & $\ldots$ & $\ldots$ & - \\
\hline
\end{tabular}

${ }^{\mathrm{a}} \mathrm{H}=$ healthy.

${ }^{\mathrm{b}} \mathrm{EM}=$ electron microscopy.

${ }^{\mathrm{c}} \mathrm{PAb}=$ polyclonal antibody.

$\mathrm{d}+=$ positive, $-=$ negative, $\ldots=$ not tested.

e $\mathrm{A} 2$ and $\mathrm{C} 2=$ monoclonal antibodies.

${ }_{\mathrm{f}}$ PTA-ELISA and ATA-ELISA = plate-trapped antigen and antibody-trapped antigen enzyme-linked immunosorbent assay, respectively.

Table 2. Antibody-trapped antigen enzyme-linked immunosorbent assay (ATA-ELISA) ${ }^{\mathrm{a}}$ comparing the detection of peach mosaic virus (PMV) and cherry mottle leaf virus (CMLV) in Chenopodium quinoa with either PMV polyclonal antibody (PAb) or CMLV PAb as the primary antibody, and CMLV monoclonal antibody A2 as the secondary antibody

\begin{tabular}{lcc}
\hline & \multicolumn{2}{c}{ ATA-ELISA } \\
\cline { 2 - 3 } Samples & PMV PAb & CMLV PAb \\
\hline C. quinoa, healthy & $0.021 \mp 0.004^{\mathrm{b}}$ & $0.092 \mp 0.012^{\mathrm{b}}$ \\
C. quinoa with CMLV & $0.917 \mp 0.029^{\mathrm{c}}$ & $1.600 \mp 0.118^{\mathrm{c}}$ \\
C. quinoa with PMV & $1.133 \mp 0.054^{\mathrm{c}}$ & $0.500 \mp 0.017^{\mathrm{c}}$ \\
\hline
\end{tabular}

${ }^{a}$ Mean absorbance values ( $\mp$ standard deviation) at $405 \mathrm{~nm}, 60 \mathrm{~min}$ after addition of the substrate.

b $n=16$.

${ }^{\mathrm{c}} n=32$. these plants. Conversely, CMLV was successfully bud-transmitted to Bing cherry, mahaleb rootstock, and Elberta peach. Typical mottle leaf symptoms were observed on Bing cherry and mild symptoms of vein clearing and chlorosis were observed near the leaf midribs of CMLVinoculated Elberta trees.

Mechanical transmission. Two of the three inoculated $C$. quinoa seedlings developed mild chlorotic mosaic on the young expanding leaves 21 days after rubinoculation with extracts from symptomatic leaves of Elberta infected with peach mosaic, isolate CA-1, triturated in PPMP. These leaves later became chlorotic and epinastic and the plants were slightly stunted. The virus was readily mechanically transmitted from $C$. quinoa to $C$. amaranticolor, C. quinoa, and N. occidentalis in either potassium phosphate buffer or Tris- $\mathrm{MgSO}_{4}$. Symptoms developed in 9 to 11 days. Both $C$. amaranticolor and $C$. quinoa were identified as local lesion hosts for PMV, with lesions appearing 3 to 5 days post-inoculation.

Electron microscopy and virus purification. Filamentous virions $752 \mathrm{~nm}$ in length $(n=83$, standard deviation $=15.75)$, $9.25 \mathrm{~nm}$ in width $(n=14)$, and with striations $3.47 \mathrm{~nm}$ in pitch $(n=18)$ were observed in purified preparations of PMV.

The virus migrated as a single sedimenting component in rate density sucrose gradients, with maximum absorption of the purified virions at $260 \mathrm{~nm}$ and estimated yields of 1.5 to $1.7 \mathrm{mg} / 100 \mathrm{~g}$ of leaf tissue.

In ISEM studies, PMV and CMLV were trapped successfully using PMV PAb and CMLV PAb. Figures $2 \mathrm{~A}$ and $2 \mathrm{~B}$ show PMV and CMLV, respectively, trapped with CMLV PAb. Attempts to decorate PMV with these antibodies were not successful; however, decoration of CMLV was observed with CMLV PAb (Fig. 2B). The decoration of CMLV by CMLV PAb appeared uneven. CMLV MAb 1162-A2 and CMLV MAb 1162-C2 were not effective for the trapping or decoration of PMV or CMLV in ISEM (Table 1).

ELISA. PMV and CMLV were both detected in C. quinoa and Prunus spp. by PTA-ELISA using either homologous or heterologous polyclonal and monoclonal antibodies. The viruses were also detected by ATA-ELISA using either PMV PAb or CMLV PAb as the trapping antibody and CMLV MAb (A2 or C2) as the secondary antibody. When PMV detection and CMLV detection were compared by ATA-ELISA, the homologous polyclonal antibodies reacted more strongly than the heterologous polyclonal antibodies (Table 2). This pattern was consistent when the tests were repeated three times.

All four PM isolates (CA-1, CA-2 [in peach and nectarine], CA-3, and CO-2] were reliably detected by PTA-ELISA using CMLV MAb A2 (Table 1). 
Western blot analysis. PMV isolate CA-1 was detected by Western blot analysis using CMLV PAb, PMV PAb, and CMLV MAbs 1162-A2 and 1162-C2. The virus was detected in infected $C$. quinoa, peach, and nectarine leaf tissues. The virus coat protein subunit migrated as a single band with an electrophoretic mobility identical to that of CMLV isolate Sa 116221 (Fig. 3) and estimated to be $20.5 \mathrm{kDa}$ in size. The experiment comparing the mobility of the protein subunits and reactions of the MAbs was done twice with consistent results. The use of BSA or skim milk as the blocking agent had no effect on the reactions observed in Western blot analysis. PMV isolates CA-1, CA-2 (in peach and nectarine), $\mathrm{CA}-3$, and $\mathrm{CO}-2$ were detected by Western blot analysis using CMLV MAb A2 as the primary antibody. The virus-associated band was not observed in any of the healthy control samples tested.

dsRNA extraction and analysis. The time of extraction of PMV-associated and CMLV-associated dsRNAs from C. quinoa was found to be critical, with 9 to 12 days post-inoculation optimal for successful extraction. The dsRNA profiles of PMV and CMLV were similar (Fig. 4). Four prominent bands of high molecular mass were observed, with estimated sizes of 7.0, $6.4,4.2$, and $1.9 \times 10^{6} \mathrm{Da}$. A number of bands of low molecular mass ranging in size from approximately 1.3 to $0.3 \times 10^{6}$

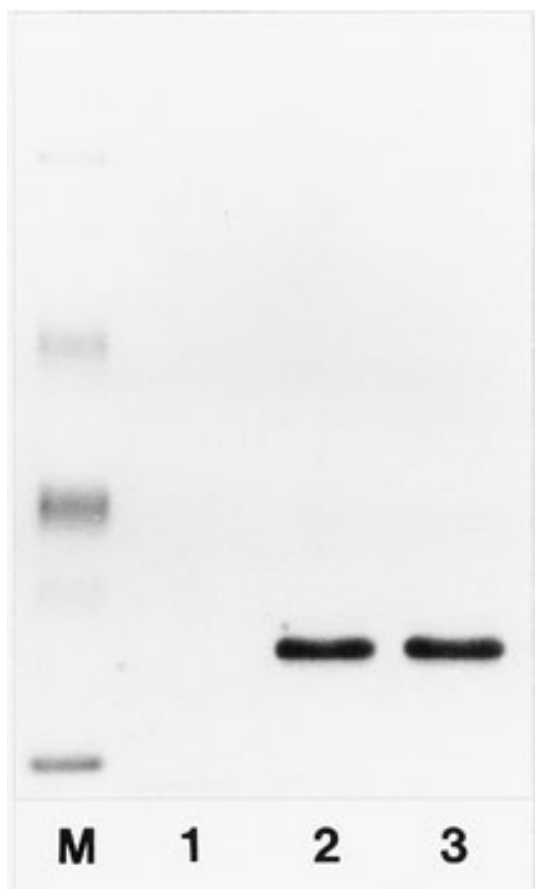

Fig. 3. Western blot analysis of cherry mottle leaf virus (CMLV) and peach mosaic virus (PMV) using CMLV monoclonal antibody 1162-A2. Lane M, Bio-Rad prestained molecular mass standards; lane 1, healthy Chenopodium quinoa; lane 2, C. quinoa infected with CMLV; and lane 3, C. quinoa infected with PMV (isolate CA-1).
Da were also observed. These low-mass bands appeared with varying degrees of resolution with each extraction.

Viroid assay. The PLMVd-specific cRNA probe hybridized with tissue blots prepared from the petioles of the known D165 PLMVd-infected control plants. No reaction was observed with the tissue blots of either the healthy or peach mosaic-affected Elberta plants (Fig. 5).

\section{DISCUSSION}

A filamentous virus (PMV) has been identified as the causal agent of peach mosaic disease. The virus, PMV isolate CA-1, which was originally mite-transmitted, was mechanically transmitted from diseased peach to $C$. quinoa. The virus was purified and a polyclonal antibody produced. This antibody readily detected the virus in extracts from the peach mosaicaffected trees tested, including isolates originally obtained through eriophyid mite transmissions. Other factors such as symptomatology, host range, and physical properties are consistent with the association of this virus to peach mosaic disease. The particle size of 752 by $9.52 \mathrm{~nm}$ with striations $3.47 \mathrm{~nm}$ in pitch supports the findings of Creamer et al. (4), who reported the presence of flexuous virus-like particles in peach mosaic-affected material. PMV was not transmitted to P. mahaleb or

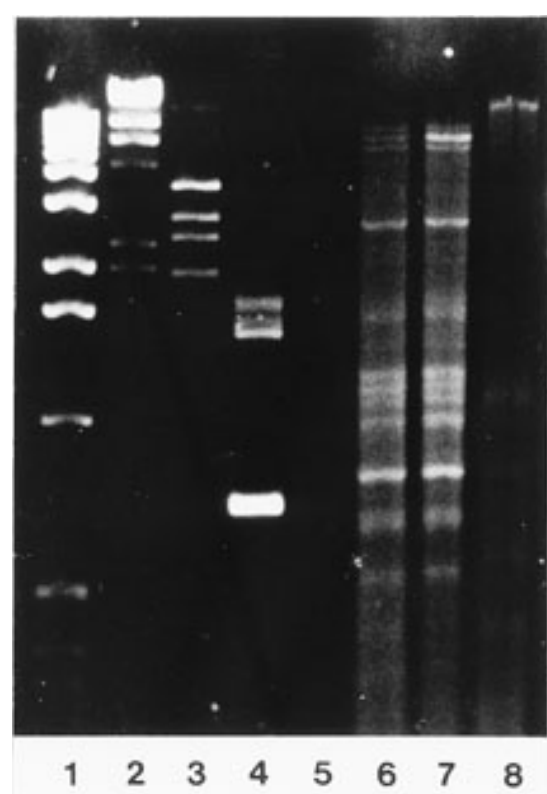

Fig. 4. Comparison of the electrophoretic mobility of the dsRNAs associated with cherry mottle leaf virus (CMLV)- and peach mosaic virus (PMV)-infected Chenopodium quinoa. Lane 1, 1-kilobase DNA ladder (Gibco BRL); lane 2, lambda/Hind III DNA markers (Stratagene, La Jolla, CA); lane 3, dsRNA from Aspergillus foetidus; lane 4, dsRNA from Penicillium stoloniferum; lane 5, healthy $C$. quinoa; lane 6, C. quinoa infected with CMLV; lane 7, C. quinoa infected with PMV; and lane 8, dsRNA of Phaseolus vulgaris cv. Black Turtle Soup bean, molecular mass $=8.0 \times 10^{6}$ Da. to $P$. avium $\mathrm{cv}$. Bing, which is consistent with the report by Pine (21). In a parallel study, CMLV was bud-transmitted to Bing cherry, mahaleb cherry, and Elberta peach.

The polyclonal antibody PMV-PAb was used to detect PMV in C. quinoa and peach by PTA-ELISA, ATA-ELISA, and Western blot analysis. PMV PAb cross-reacted with CMLV in ELISA and Western blot analysis. CMLV PAb and CMLV MAbs also cross-reacted with PMV in ELISA and Western blot analyses. Spurious serological cross-reactions can be eliminated by using skim milk as a blocking agent (24). Skim milk had no effect on the observed crossreactions of PMV and CMLV antibodies when used in ELISA and Western blot analyses. PMV and CMLV could be distinguished in ATA-ELISA assay. ATAELISA in which a particular PAb was used as the trapping antibody gave a stronger reaction with the detection of the homologous virus than with the heterologous virus. The viruses could also be distinguished in ISEM studies using CMLV $\mathrm{PAb}$; both viruses were successfully trapped but only CMLV appeared to be decorated (partial). It is possible that optimal conditions for binding were not achieved, the epitopes on PMV may not have been accessible for decoration, or that efficient binding of this antibody to PMV does not occur.

Two viruses infecting Prunus spp. are known to be transmitted by eriophyid mites, PMV (by Eriophyes insidiosus Keifer \& Wilson; 13) and CMLV (by E. inaequalis Wilson and Oldfield; 19). Data presented above demonstrate that these two viruses are very similar. Both are filamentous particles, both have the same coat protein size $(20.5 \mathrm{kDa} ; 8)$, the dsRNA profiles are identical, and both are serologically related. They differ, however, in their host range and symptomatology and their homologous serological reactions are stronger than the heterologous serological reactions. Unlike CMLV, PMV does not infect $P$. avium (Bing) and $P$. mahaleb. CMLV induced symptoms in Elberta which were mild and in some cases transient, quite unlike the symptoms induced by PMV infection. PMV and CMLV ap-

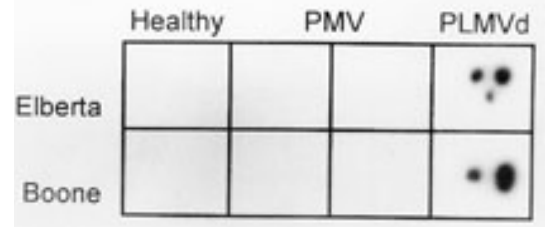

Fig. 5. Tissue blots showing positive reactions of the ${ }^{32} \mathrm{P}$-labeled peach latent mosaic viroid (PLMVd)-specific cRNA probe with PLMVdinfected Elberta peach and Boone County seedlings, and negative results with peach mosaic-affected (PMV-infected) plants and healthy controls. 
pear to be closely related viruses, possibly strains of the same virus with different host range and symptomatology.

Because of the serological relationship between these viruses, antibodies developed against CMLV were effectively used by Oldfield et al. (20) for the detection of PMV. Using antibodies developed against CMLV, they consistently obtained positive reactions in ELISA tests with extracts from peach mosaic-diseased trees. The serological cross-reactions extended to all isolates tested.

In contrast, we observed no relationship between PLMVd and peach mosaic disease. The viroid could not be detected in Elberta plants that were bud-inoculated with peach mosaic and showed typical peach mosaic symptoms. This agrees with the results reported by Hadidi et al. (6), who were unable to detect the viroid in plants known to be affected by peach mosaic. Also, symptoms, when they occurred on PLMVd-infected peach, differed significantly from those produced by PMV, and were more typical of those described for peach blotch disease (18).

PMV is an important virus with severe effects on some stone fruits species (17). The disease spreads quickly and, consequently, rigorous control programs were implemented in the United States in 1934 (15). This study has resulted in the isolation of the causal virus and the development of serological tools for reliable and rapid detection of the virus, and should contribute significantly to further study and control of this important disease.

\section{ACKNOWLEDGMENTS}

We thank S. Godkin for her technical assistance and for the photography; L. Skrzeczkowski for the viroid assays; $\mathrm{H}$. Larsen for generously providing samples of the various peach mosaic isolates; and B. Coutts for samples of dsRNA from Aspergillus foetidus and Penicillium stoloniferum.

\section{LITERATURE CITED}

1. Bar-Joseph, M., Hull, R., and Lane, L.C. 1974. Biophysical and biochemical characterization of apple chlorotic leafspot virus. Virology 62:563-566.

2. Bodine, E. W. 1934. Occurrence of peach mosaic in Colorado. Plant Dis. Rep. 18:132

3. Bodine, E. W. 1936. Peach mosaic disease in Colorado. Colo. Agric. Exp. Stn. Bull. 421.

4. Creamer, R., Gispert, C., and Oldfield, G. 1994. Partial characterization of peach mosaic virus. Pages 21-23 in: Proc. Int. Symp.: Rose rosette and other eriophyid mite-transmitted plant disease agents of uncertain etiology. Iowa State University, Ames.

5. Desvignes, J. C. 1986. Peach latent mosaic and its relation to peach mosaic and peach yellow mosaic virus diseases. Acta Hortic. 193:51-57.

6. Hadidi, A., Giunchedi, L., Shamloul, A. M., Poggi-Pollini, C., and Amer, M. A. 1997. Occurrence of peach latent mosaic viroid in stone fruits and its transmission with contaminated blades. Plant Dis. 81:154-158.

7. Hutchins, L. M. 1932. Peach mosaic-A new virus disease. Science 76:123.

8. James, D. 1992. Partial characterization of a closterovirus-like particle transmitted from cherry (Prunus avium) infected with several viral diseases. Acta Hortic. 308:39-44.

9. James, D. 1994. Cherry mottle leaf-The fulfilment of Koch's postulates. Pages 17-20 in: Proc. Int. Symp.: Rose rosette and other eriophyid mite-transmitted plant disease agents of uncertain etiology. Iowa State University, Ames.

10. James, D., and Howell, W. E. 1993. Comparisons of cherry mottle leaf and a virus associated with peach mosaic disease. (Abstr. 17.1.20.) Int. Congr. Plant Pathol. 6th, Montreal.

11. James, D., and Mukerji, S. 1993. Mechanical transmission, identification and characterization of a virus associated with mottle leaf in cherry. Plant Dis. 77:271-275.

12. James, D., and Mukerji, S. 1996. Comparison of ELISA and immunoblotting techniques for the detection of cherry mottle leaf virus. Ann. Appl. Biol. 129:13-23.

13. Keifer, H. H., and Wilson, N. S. 1955. A new species of eriophyid mite responsible for the vection of peach mosaic virus. Bull. Calif. Dep. Agric. 44:145-146.
14. Laemmli, U. K. 1970. Cleavage of structural proteins during the assembly of the head of bacteriophage T4. Nature 227:680-685.

15. Larsen, H. J., and Oldfield, G. N. 1995. Peach mosaic. Pages 67-68 in: Compendium of Stone Fruit Diseases. J. M. Ogawa. E. I. Zehr, G. W. Bird, D. F. Ritchie, K. Uriu, and J. K. Uyemoto, eds. APS Press, St. Paul, MN.

16. Morris, T. J., and Dodds, J. A. 1979. Isolation and analysis of double-stranded RNA from virus infected plants and fungal tissue. Phytopathology 69:854-858.

17. Nemeth, M. 1986. Virus, Mycoplasma and Rickettsia Diseases of Fruit Trees. Akademiai Kiado, Budapest.

18. Nichols, C. W. 1976. Peach blotch. Pages 5657 in: Virus Diseases and Noninfectious Disorders of Stone Fruits in North America. R. M. Gilmer, J. D. Moore, G. Nyland, M. F. Welsh, and T. S. Pine, eds. U. S. Dep. Agric. Agric. Handb. No 437.

19. Oldfield, G. N. 1970. Mite transmission of plant viruses. Annu. Rev. Entomol. 15:343380.

20. Oldfield, G. N., Creamer, R., Gispert, C. Osorio, F., Rodriguez, R., and Perring, T. M. 1995. Incidence and distribution of peach mosaic and its vector, Eriophyes insidiosus (Acari:Eriophyidae) in Mexico. Plant Dis. 79:186-196.

21. Pine T. S. 1976. Peach mosaic. Pages $61-70$ in: Virus Diseases and Noninfectious Disorders of Stone Fruits in North America. R. M Gilmer, J. D. Moore, G. Nyland, M. F. Welsh, and T. S. Pine, eds. U. S. Dept. Agric. Handb. No 437.

22. Skrzeczkowski, L. J., Howell, W. E., and Mink, G. I. 1996. Occurrence of peach latent mosaic viroid in commercial peach and nectarine cultivars in the U.S. Plant Dis. 80:823.

23. Torrance, L. 1992. Serological methods to detect plant viruses: production and use of monoclonal antibodies. Pages 7-33 in: Techniques for the Rapid Detection of Plant Pathogens. R. A. C. Jones and L. Torrance, eds. The Lavenham Press Ltd., Suffolk. England.

24. Zimmermann, D., and Van Regenmortel, M. H. V. 1989. Spurious cross-reactions between plant viruses and monoclonal antibodies can be overcome by saturating ELISA plates with milk proteins. Arch. Virol. 106:15-22. 